\title{
Abordarea terapeutică a bolii diareice acute la pacientul pediatric
}

\author{
Andreea Ligia Dincă',2, Cristina Oana Mărginean ${ }^{1,2}$, Iulia Armean', \\ Vlăduț Ştefănuț Săsăran², Lorena Elena Meliț1,2 \\ ${ }^{1}$ Clinica Pediatrie I, Spitalul Clinic Judeţean de Urgenţă, Tg. Mureş, România \\ ${ }^{2}$ Universitatea de Medicină şi Farmacie, Tg. Mureş, România
}

\begin{abstract}
REZUMAT
Obiective. În abordarea problematicii bolii diareice acute (BDA) la pacientul pediatric, ne-am fixat ca obiectiv principal o evaluare amănunţită a etiologiei şi factorilor de risc şi, pe de altă parte, evaluarea raportului risc/ beneficiu în ceea ce priveşte justificarea antibioterapiei în tratamentul BDA la pacientul pediatric.

Material şi metodă. Am efectuat un studiu analitic descriptiv, retrospectiv, pe un lot de 125 pacienţi, internaţi în Clinica Pediatrie I Tg. Mureş pe parcursul anului 2016 (ianuarie-decembrie) cu diagnosticul de boală diareică acută (BDA).

Rezultate. Din totalul de 125 de pacienţi, s-a identificat o etiologie bacteriană a BDA în 23 de cazuri $(18,4 \%)$. Pe de altă parte, s-a observat faptul că 84 de pacienţi au primit tratament antibiotic (67,2\%), 110 pacienţi (88\%) tratament simptomatic iar în $60 \%$ din cazuri (75 pacienţi) s-a asociat şi tratament probiotic. Durata medie de spitalizare a fost de 5 zile, durată influenţată de prezenţa/absenţa unor factori de risc precum febra, sindromul inflamator, tulburările hidroelectrolitice sau sindromul de deshidratare acută, factori care au prelungit perioada de spitalizare cu până la 2 zile $(p<0,05)$.

Concluzii. Antibioterapia trebuie utilizată raţional şi justificat în tratamentul BDA, analizând foarte atent raportul risc/beneficiu. Considerând caracterul autolimitant şi prognosticul favorabil al bolii, concluzionăm prin faptul că ne aflăm în faţa unui abuz de antibiotice în cazul pacienţilor pediatrici cu BDA.
\end{abstract}

Cuvinte cheie: boală diareică acută, copil, antibiotice

\author{
Abrevieri \\ BDA - boală diareică acută, \\ BII - boli inflamatorii intestinale; \\ Ig E - imunoglobuline E; \\ $\mathrm{PCR}$ - proteina $\mathrm{C}$ reactivă; \\ SDA - sindrom de deshidratare acută
}

\section{INTRODUCERE}

Gastroenterita sau boala diareică acută (BDA) - este un termen nespecific care descrie o serie de fenomene patologice cu sediul la nivelul tractului intestinal, determinate de un agent patogen, de natură virală, bacteriană sau parazitară. Morbiditatea ridicată asociată acestei patologii (aproape $1.8 \mathrm{mi}-$ liarde episoade de BDA/an), are un impact major în domeniul sănătății, atât pe plan clinic, cât şi pe plan socio-economic (1).

Cei mai frecvenți factori etiologici ai BDA, sunt reprezentați de agenții virali. Pe de altă parte, Sal- monella spp., Shigella spp. şi speciile de Campylobacter reprezintă cele mai frecvente cauze bacteriene de BDA în rândul populaţiei pediatrice $(2,3)$.

Principiile de tratament în BDA cuprind: terapia de rehidratare orală, alimentaţia enterală, regimul igienico-dietetic, precum şi terapiile adjuvante, cum ar fi probioticele. Tratamentul etiologic trebuie luat în considerare în toate cazurile în care a fost identificată etiologia. Utilizarea probioticelor în profilaxia şi tratamentul BDA este frecvent benefică. Pe lângă rolul de reechilibrare a florei intestinale, probioticele joacă un rol important de stimulare a imunității gazdei - prin fenomenul de „downre- 
gulation" al citokinelor pro-inflamatorii şi cel de „upregulation“" al citokinelor antiinflamatorii (1). Tratamentul antibiotic timpuriu în cazurile selectate de BDA la copil poate duce la scăderea duratei şi a severității bolii, precum şi la prevenirea complicațiilor. Utilizarea lor pe scară largă - şi, uneori, fără indicație - a dus la dezvoltarea rezistenței bacteriene. De cele mai multe ori, decizia inițierii tratamentului antibiotic este una empirică, fără o justificare medicală solidă (4).

\section{MATERIAL ŞI METODĂ}

Am efectuat un studiu analitic descriptiv, retrospectiv, în care au fost incluşi 125 pacienți, internați în Clinica Pediatrie I Tg. Mureş pe parcursul anului 2016 (ianuarie-decembrie). Obiectivul principal al studiului a fost o evaluare amănunțită a etiologiei şi factorilor de risc pentru BDA şi, totodată, evaluarea raportului risc/beneficiu în ceea ce priveşte justificarea antibioterapiei în tratamentul BDA.

Criteriile de includere: pacienți internați în Clinica Pediatrie I Tg. Mureş în intervalul 1 ianuarie 2016 - 31 decembrie 2016, cu vârsta cuprinsă între 0 şi 18 ani, care s-au prezentat acuzând simptomatologie de BDA sau care au manifestat un episod de BDA pe parcursul internării. Criteriile de excludere din studiu au constat în: prezența diareei de tip cronic (cu durată de peste 14 zile), date clinice sau paraclinice incomplete. Datele au fost analizate şi prelucrate cu ajutorul programului de statistică SPSS software (teste Mann Whitney şi Chi-pătrat). Intervalul de confidență a fost setat la o valoare de $95 \%$, iar rezultatele au fost considerate semnificative din punct de vedere statistic pentru o valoare a pragului de semnificație ,p"

\section{REZULTATE}

Incidența BDA în Clinica Pediatrie I a fost de $7,3 \%$ (125 de cazuri) din totalul internărilor (1702) corespunzătoare anului 2016. Lotul de studiu a cuprins 125 de pacienți, dintre care $71(56,8 \%)$ au fost reprezentanți ai sexului masculin şi $54(43,2 \%)$ ai sexului feminin. Pacienții au fost distribuiți pe grupe de vârstă, după cum urmează: sugari - 60 pacienți (48\%), copii mici cu vârsta între 1 şi 3 ani -37 $(29,6 \%)$, şi copii cu vârsta peste 3 ani - 28 pacienți $(22,4 \%)$. Aşadar, aproape jumătate din cazuistică (48\%) a fost identificată în rândul sugarilor. Am obținut un procent de $71,2 \%$ (89) dintre cazuri manifestat în timpul anotimpului rece şi 28,8\% (36 de cazuri) în sezonul cald. În ceea ce priveşte etiologia BDA, s-a observat o etiologie bacteriană în 23 de cazuri (18,4\%), în timp ce infecțiile de natură virală au constituit 53 dintre cazuri $(42,4 \%)$. Restul cazurilor de diaree acută au fost atribuite altor etiologii (vezi Tabel 1).

Infecția intestinală cu rotavirus a fost pusă în evidență la un număr de 13 pacienți $(10,4 \%)$ din totalul cazurilor de BDA. Dintre agenții de natură virală, s-au mai testat adenovirusurile. Referitor la infecțiile intestinale de etiologie bacteriană, prin coprocultură s-au testat următoarele specii: Campylobacter, Escherichia coli (E. coli) enteropatogen, Yersinia, Shigella, Salmonella. Consecutiv testării, s-au identificat agenții infecțioşi în 4 cazuri, dintre care $2 \mathrm{cu} E$. coli enteropatogen, un caz cu Salmonella sppecies. A fost identificat un caz de infecție intestinală cu Clostridium difficile - pacientă în vârstă de 2 ani şi jumătate, la care s-a confirmat diagnosticul prin testul la GDH (glutamat dehidrogenaza), care a fost pozitiv, iar, ulterior, prin evidențierea toxinelor A şi B din materiile fecale. Examenul coproparazitologic a fost pozitiv în 3 cazuri. Coprocultura ne oferă informații cu privire la etiologie în rare cazuri. S-au considerat de origine bacteriană cazurile de $\mathrm{BDA}$ care au asociat stare generală profund alterată, hiperpirexie, leucocitoză cu neutrofilie, prezența leucocitelor şi a elementelor patologice în materiile fecale, precum şi prezența unui sindrom inflamator marcat (PCR modificat $>10 \mathrm{mg} / \mathrm{dl}$ ). Disbioza a fost incriminată ca factor etiologic al BDA în cazurile specificate, la care fenomenul de disbioză a fost descris în rezultatul coproculturii sau la pacienții care au urmat un tratament antibiotic prelungit şi au dezvoltat simptomatologie caracteristică BDA.

TABELUL 1. Etiologie BDA

\begin{tabular}{|l|c|c|c|}
\hline \multirow{2}{*}{ ETIOLOGIE } & Agent identificat & Nr. cazuri & $\begin{array}{c}\text { Procent } \\
\text { BDA }\end{array}$ \\
\hline \multirow{2}{*}{$\begin{array}{l}\text { BACTERIANĂ } \\
\text { (18,4\%) }\end{array}$} & E.coli enteropatogen & $\mathbf{2}$ & $1,6 \%$ \\
\cline { 2 - 4 } & Clostridium difficile & $\mathbf{1}$ & $0,8 \%$ \\
\cline { 2 - 4 } & Salmonella spp. & $\mathbf{1}$ & $0,8 \%$ \\
\cline { 2 - 4 } & Altele & $\mathbf{1 9}$ & $15,2 \%$ \\
\hline VIRALĂ & Adenovirus & $\mathbf{1 3}$ & $10,4 \%$ \\
\hline 53 cazuri & Alte e ologii virale & $\mathbf{3 9}$ & $0,8 \%$ \\
\hline (42,4\%) & Oxiuriază & $\mathbf{3}$ & $2,4 \%$ \\
\hline $\begin{array}{l}\text { PARAZITARĂ } \\
\text { (4 cazuri) }\end{array}$ & Ig E specific & $\mathbf{9}$ & $7,2 \%$ \\
\hline $\begin{array}{l}\text { ALERGICĂ } \\
\text { (16 cazuri) }\end{array}$ & - & $\mathbf{8}$ & $6,4 \%$ \\
\hline $\begin{array}{l}\text { BII } \\
\text { (8 cazuri) }\end{array}$ & - & $\mathbf{2 1}$ & $16,8 \%$ \\
\hline $\begin{array}{l}\text { DISBIOZĂ } \\
\text { (21 cazuri) }\end{array}$ & - & $\mathbf{2 7}$ & $21,6 \%$ \\
\hline IDIOPATIC & - & $\mathbf{1 2 5}$ \\
\hline TOTAL: & & & \\
\hline
\end{tabular}


Printre simptomele frecvent identificate în studiu, s-au numărat: vărsăturile (56 de pacienți) şi prezența febrei (64 de pacienți). Din punct de vedere paraclinic, s-a observat existența sindromului inflamator evidențiat prin PCR (proteina $\mathrm{C}$ reactivă) pozitiv la 55 de pacienți (44\%), a diselectrolitemiei în 49 de cazuri $(39,2 \%)$ şi a sindromului de deshidratare acută (SDA) în 82 dintre cazuri $(65,6 \%)$.

Tratamentul administrat a cuprins antibioterapie, simptomatice, probiotice. S-a observat faptul că 84 de pacienți au primit tratament antibiotic (67,2\%), în timp ce 110 pacienți (88\%) au necesitat tratament simptomatic. S-au utilizat ca simptomatice medicamente antiemetice de tipul metoclopramidului, antidiareice de tipul diosmectitei şi racecadotrilului, iar ca antispastic s-a utilizat drotaverină injectabilă. În $60 \%$ dintre cazuri (75), s-au asociat probiotice la tratament.

Durata medie de spitalizare a fost de 5 zile. S-a constatat o asociere semnificativ statistică între prezența febrei $(\mathrm{p}=0,0164)$, a sindromului inflamator pozitiv $(p=0,0124)$, a diselectrolitemiilor $(p$ $=0,0064)$, a sindromului de deshidratare acută $(\mathrm{p}=$ $0,0034)$ şi creşterea numărului mediu de zile de spitalizare (Tabelul 2).

TABELUL 2. Influența factorilor de risc asupra perioadei de spitalizare

\begin{tabular}{|l|c|c|c|}
\hline MODIFICĂRI & DA & NU & Valoare „p“ \\
\hline & \multicolumn{2}{|c|}{ Număr mediu zile spitalizare } \\
\hline FEBRĂ & 5 & 4 & 0,0164 \\
\hline PCR pozitiv & 6 & 4 & 0,0124 \\
\hline DISELECTROLITEMIE & 5,5 & 4 & 0,0064 \\
\hline SDA & 5 & 3 & 0,0034 \\
\hline
\end{tabular}

Sexul nu are influență semnificativ statistică asupra dezvoltării BDA $(\mathrm{p}=0,66)$. Deşi $48 \%$ dintre pacienți au fost sugari, nu s-au pus în evidență asocieri semnificativ statistice între grupele de vârstă studiate şi apariţia BDA. Am evaluat, de asemenea, impactul sezonier asupra dezvoltării BDA, însă nu au fost identificate asocieri semnificativ statistice $(\mathrm{p}=0,48)$.

\section{DISCUŢII}

BDA reprezintă una dintre cauzele principale de morbiditate şi chiar de mortalitate în rândul populației pediatrice. Studiul de față a analizat 125 de cazuri de BDA, din punct de vedere al incidenței pe sexe, grupe de vârstă, etiologie, factori de risc şi abordare terapeutică.

Studiile de specialitate semnalează morbiditate crescută din cauza BDA la copilul mic şi în special la sugar (5). În cadrul studiului de față, incidența cea mai mare a BDA s-a constatat la sugari (60 subiecți $-48 \%$ ) şi, în proporții aproximativ egale, la celelalte grupe de vârstă $(29,6 \%$ la copii mici şi, respectiv, 22,4\% peste vârsta de 3 ani). Vârsta de sugar reprezintă o categorie aparte în patologia pediatrică din cauza susceptibilității ridicate la deshidratare, a simptomatologiei nespecifice care poate însoți BDA şi a riscului crescut de complicații. Contrar aşteptărilor, studiul nu a evidențiat o asociere semnificativ statistică între diagnosticul principal de BDA şi grupele de vârstă studiate $(\mathrm{p}=0,12)$.

Influența sezonieră asupra apariției BDA este frecvent incriminată în literatură. De obicei, se asociază gastroenterocolitelor cu rotavirus şi se descrie o predilecție pentru sezonul rece (noiembrie-aprilie) (6). Sezonalitatea BDA este într-un declin progresiv datorită schemelor de imunizare anti-rotavirus implementate la nivel mondial $(6,7)$. Studiul actual a evidenţiat parţial caracterul de sezonalitate al BDA, astfel că $71,2 \%$ dintre cazuri au fost diagnosticate în sezonul rece, comparativ cu $28,8 \%$ care s-au internat în sezonul cald. Cu toate aceastea, nu s-a obținut o corelație cu semnificație statistică cu privire la rolul sezonului în dezvoltarea BDA ca prim diagnostic $(\mathrm{p}=0,48)$.

Principalii agenți etiologici au fost de natură virală $(42,2 \%)$, dintre care aproximativ un sfert au fost infectii cauzate de rotavirus. Aceste rezultate sunt în concordanță cu alte date din literatura de specialitate, care descriu prevalența crescută a infecțiilor cu rotavirus în cadrul gastroenterocolitelor de natură virală $(8,9)$.

Din lotul de 23 de pacienți cu BDA de origine bacteriană, am identificat agentul etiologic în doar 4 cazuri. Putem afirma că metoda de diagnostic este cu specificitate înaltă, însă cu rată slabă de depistare a agentului etiologic în BDA de origine bacteriană. Una dintre limitările studiului se referă la imposibilitatea testării mai multor specii bacteriene prin coprocultură şi, consecutiv, la lipsa unui diagnostic etiologic de certitudine în cazul bolii diareice de origine bacteriană. De asemenea, o testare mai vastă a speciilor virale ar fi putut aduce un aport semnificativ la calitatea ştiințifică a studiului.

Tabloul clinic în BDA poate fi nespecific, fiind dominat de diaree - cu sau fără elemente patologice, la care se asociază alte simptome gastro-intestinale/sistemice. Severitatea bolii depinde în mare măsură de gradul de deshidratare al pacientului şi se corelează cu durata spitalizării, complexitatea tratamentului şi momentul inițierii terapei.

Febra nu reprezintă un factor de risc pentru apariția BDA şi este un simptom nespecific. Totuşi, 
studiile din domeniu asociază frecvent febra cu un prognostic nefavorabil în $\operatorname{BDA}(10,11)$. Se poate afirma acelaşi lucru despre prezența sindromului inflamator (PCR pozitiv), a diselectrolitemiei şi a SDA. Nu am identificat modificări patognomonice în ceea ce priveşte tabloul paraclinic al BDA.

Durata medie de spitalizare a pacienților din lotul studiat a fost de 5 zile. Perioada de spitalizare prezintă efecte negative atât din punct de vedere socio-economic, cât şi asupra calității vieții bolnavului şi a aparţinătorilor. Aşadar, BDA este o patologie cu un impact socio-economic semnificativ (12).

S-a constatat faptul că prezența febrei şi evidentierea PCR-ului, a diselectrolitemiilor sau a SDA au un impact semnificativ asupra prelungirii perioadei de spitalizare a pacienților. Acest fapt demonstrează caracterul multifactorial al BDA şi importanța managementului corect al bolii în prezența factorilor de risc expuşi anterior.

Potrivit ghidurilor de specialitate (11), antibioticele nu se utilizează de primă intenție în managementul BDA şi sunt rezervate cazurilor cu indicație specifică. Din punct de vedere al tratamentului, în studiul actual, se remarcă o utilizare importantă a antibioterapiei $(67,2 \%)$ în abordul terapeutic al BDA, în discordanță cu procentul de 18,4\% identificat ca fiind reprezentativ pentru etiologia bacteriană. Principalele tipuri de antibiotice utilizate au fost penicilinele cu spectru larg (Ampicilina), cefalosporinele de generația 2 şi 3 (Cefuroxim, Ceftriaxonă), iar în cazurile selectate (sepsis) s-au utilizat antibiotice cu spectru larg, de tipul carbapenemelor. Procentul crescut al pacienților tratați cu agenți antiinfecțioşi sugerează o alegere nejustificată în utilizarea antimicrobienilor. Subliniem importanța limitării antibioterapiei din cauza riscului de creştere a rezistenței la antibiotice. În plus, abuzul sau utilizarea irațională de antibiotice pot duce la apariția disbiozelor intestinale şi apariția consecutivă a tulburărilor de tranzit intestinal.

Un aspect intens studiat în medicina contemporană este asocierea probioticelor în bolile funcționale intestinale. Aceste preparate îndeplinesc roluri esențiale în restabilirea echilibrului florei intestinale, în imunitatea umorală intestinală şi în reglarea tranzitului intestinal (12). Studiul de față indică utilizarea probioticelor în $60 \%$ dintre cazuri, indicaţie justificată având în vedere procentul crescut de pacienți trataţi cu medicamente antibacteriene.

\section{CONCLUZII}

Rotavirusul este cel mai frecvent agent etiologic în gastroenteritele virale; susţinem, aşadar, vaccinarea anti-rotavirus pentru reducerea morbidității asociate. Clinicianul trebuie să fie conştient de prezența unor factori de risc care sunt asociați cu prelungirea perioadei de spitalizare în BDA, precum febra, prezența unui PCR pozitiv sau a tulburărilor hidroelectrolitice. Antibioterapia trebuie utilizată raţional şi justificat în tratamentul BDA, analizând foarte atent raportul risc/beneficiu în favoarea pacientului. Aşadar, luând în considerare caracterul autolimitant şi prognosticul favorabil al bolii, concluzionăm prin faptul că în momentul actual ne aflăm în fața unui abuz de antibiotice în cazul pacienților pediatrici cu BDA. Clinicianul ar trebui să pună mai mult accent pe tratamentul simptomatic al BDA în detrimentul celui etiologic, deoarece antibioterapia nu are impact semnificativ în ceea ce priveşte prognosticul final al bolii. 